\title{
THE LUJAVRITE AND KHIBINITE BODIES IN THE POÇOS DE CALDAS ALKALINE MASSIF, SOUTHEASTERN BRAZIL: A STRUCTURAL AND PETROGRAPHIC STUDY
}

\author{
HORSTPETER H. ULBRICH \& MABEL N. C. ULBRICH
}

\begin{abstract}
RESUMO OS CORPOS DE LUIAVRITO E KHIBINITO DO COMPLEXO ALCALINO DE POÇOS DE CALDAS, SUDESTE DO BRASIL: UM ESTUDO ESTRUTURAL E PETROGRÁFICO Dois pequenos corpos de lujavritos e khibinitos, oriental e ocidental, afloram no anel notte do macico alcalino de Poços de Caldas, SE do Brasil. Mapeamento detalhado revela, no centro da estrutura do corpo ocidental, melhor exposto, do maciço alcalino de Poços de Caldas, SẼ do Brasil. Mapeático e de aspecto gnáissico (lujavrito, Lu I), com foliação subhorizontal, e variedade um eudialita nefelina sienito de granulação grossa, mesocráco de aspecto gnáss (NeS) traquitóides (NeS I e II), circundados por um cudialita mais fina (Lu II) de borda. Como envelope externo, aparecem dois nefelina sienitos (NeS) traquitoides (Nem uma sequiência concordante (em parte incompleta no oriental) mostrando as facies Lu I - Lu II - NeS I - NeS II, com mergulhos moderados a fortes na região de contato entre elas; por for espalha-se o NeS III. As rochas encaixantes são tinguaitos e um NeS cinza anterior, NeS IV. Tinguaitos são as primeiras rochas intrusivas fora, espalha-se o NoS (idades de 76-80 Ma), seguidas pela intrusão dos Nes (idades similares), com intrusão do Ne fV anta subhorizontal de magma khibinítico O A intrusão dos corpos de Lu I-II e NeS I-II foi um processo contínuo, iniciado com a invasão forçada subhociaño de líquidos residuais uma capa surgimento de magma subsequente comprimiu a massa magmán tl na borda. Ao mesmo tempo, ocorreu expansão lateral da câmara magmática. Neste lujavrítica, com estrutura foliada subhorizontal e Lu ll na borda. Ao mesmo tempo, ocora ocorrências de lujavritos (Ilímaussaq, Lovozero, maciço, magmas agpaíticos são sempre intrusões tardias. Uma comparação com outras oça processo que controla a geração das estruturas e texturas de lujavritos.
\end{abstract}

\section{Palavras chaves: Lujavritos - Chibinitos - Nefelina sienitos - Maciços alcalinos}

\begin{abstract}
Two small lujavrite-khibinite bodies, an eastern and a western one, are exposed at the northern edge of the alkaline Poços de Caldas massif, southeastern Brazil. Detailed mapping reveals at the center of the better exposed western body a coarse-grained, mesocratic, gneissic-looking eudialyte nepheline syenite (lujavrite) with a strong subhorizontal foliation (Lu I), showing at the contacts a finer-grained border gneissic-looking eudialyte nepheline syenite (lujavrite) with a strong subhorizontal follo to central lujavrites, followed by an outer shell of coarsefacies (Lu II). Two trachytoid nepheline syenites (NeS I and II) occur as an envelope to the central ing with successive foliated shells (in part absent

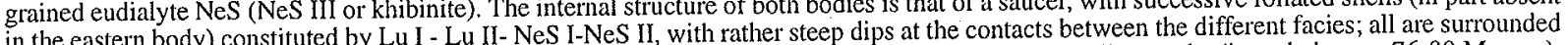
in the eastern body) constituted by Lu I - Lu II- NeS I-NeS II, with rather steep dips at the contacts between the different facies; all are surrounded by the outer NeS III. Country rocks are tinguaites and a grey NeS (NeS IV). This as ociated types. The emplacement of the lujavrite bodies was followed by the coarser rocks, with NeS IV emplaced before the lujavrites and associated types. The Magma upwelling compressed the initial a continuous process, initiated with forceful subhorizontal intrusion of strongly agpaitic magmas. Magma upwethre (Lu I) and an outer shell magma batch, generating the lujavrite caps by compaction and liquid extraction, with a foliated subhorizontal structure (Lu I) and an outer shell (Lu II). The intrusion forced at the same time a lateral expansion of the magma chamber. In this massif, agpaitic magmas appear always as late intrusions. A comparison with other occurrences (Ilimaussaq, Lovozero, Pilansberg, the Texan Trans-Pecos province) suggests that emplacement under forceful conditions may be a controlling factor in shaping the final fabric of lujavrites.
\end{abstract}

Keywords: Lujavrites - Khibinites - Nepheline syenites - Alkaline massifs

INTRODUCTION The late Cretaceous Poços de Caldas alkaline massif, southeastern Brazil (Fig. 1), with its over $800 \mathrm{~km}^{2}$, was first mentioned in early classic petrographic papers (e.g., Derby 1887 , Machado 1888). The first geologic map was made available by Ellert, Coutinho and Björnberg (Ellert 1959, Björnberg 1959, cf. also Utsumi et al. 1971, Putzer 1976). Tinguaites and phonolites (comprising together $80 \%$ of outcrops) and nepheline syenites (NeS, 17\%) are predominant (Fig. 1). Also observed is a narrow N-S trending irregular trench, close to the western margin of the district, comprising poorly exposed lava flows and predominant pyroclastic rocks $3 \%$ of outcrops, showing tuffs, breccias and agglomerates, with fragments of ankaratrites, phenocrystic rocks, etc.). Recently, additional data were presented on the petrography and mineralogy of the nepheline syenites (NeS) (Ulbrich 1983, Ulbrich 1984, Ulbrich et al. 1984, Schorscher \& Shea 1992).

Earlier K-Ar geochronological data (Amaral et al. 1967, Bushee 1974) suggested a long magmatic history (from $87 \mathrm{Ma}$ for ankaratrites to $53 \mathrm{Ma}$ for phonolite dikes; data corrected to the 1977 Steiger \& Jaeger constants lower these figures by about $2.5 \%$; Sonoki \& Garda 1988). Two whole-rock $\mathrm{Rb} / \mathrm{Sr}$ isochrons were obtained by Kawashita et al. (1984), with ages of $89.8( \pm 2.8) \mathrm{Ma}$ and an initial $\mathrm{Sr}^{87} / \mathrm{Sr}^{86}$ ratio of $0.7050( \pm 1)$ (grey NeS and a fluorite-bearing NeS), and $86.3( \pm 6.0)$ $\mathrm{Ma}$ (i.r., $0.7052 \pm 1$; lujavrites and khibinites). Shea (1992) presents two $\mathrm{Rb}-\mathrm{Sr}$ isochrons, one based on 4 whole-rock samples of the centrally-located Pedreira NeS type (age of $74.2 \pm 6.3 \mathrm{Ma}$, i.r. of $0.70511 \pm 1$ ), the other a combined mineral and whole-rock isochron (7 data points; age of $77.9 \pm 3.1 \mathrm{Ma}$, i.r. of $0.70512 \pm 1$; Ulbrich 1984 , Ulbrich \& Ulbrich 1992, Chapman et al. 1992; for ages, see especially Shea 1992).

The massif, probably emplaced as a caldera-like structure (Ellert 1959), shows at its present shallow erosion level still significant amounts of engulfed sandstones, mostly attributed to the aeolian Botucatú Formation (Ellert 1959, Björnberg 1959, Oliveira et al. 1984).

A composite intrusion (about $3 \mathrm{~km}^{2}$ ) is found on the topographically prominent Poços de Caldas northern tinguaite rim, mainly constituted by eudialyte NeS ("lujavrite and khibinite" in Fig, 1). Lujavrites are observed as two disconnected small bodies within the more abundant khibinites.

The present contribution is mainly concerned with a structural study of these two northern lujavrite-khibinite bodies, based on detailed mapping of the several petrographic facies encountered in these outcrops (see inset in Fig. 1).

PETROGRAPHY AND MINERALOGY Relevant maps are presented in figures 2 and 3. Two lujavrite types (Lu I and II) were identified, showing transition into one another. Three additional NeS (NeS I, II and III) are found as envelopes to the central lujavrites; all are Na-rich rocks. NeS IV is an earlier K-rich rock. All phaneritic rocks are intrusive into the northern-rim tinguaites. Macroscopic and microscopic features are depicted in figures 4,5 and 6 ; modes are presented in Table 1.

Macroscopic descriptions The type I lujavrite (Lu I) is a mesocratic, foliated, coarse-grained inequigranular NeS. Feldspars are present as oriented idiomorphic thin plates (up to $2-3 \mathrm{~cm}$ in length). Nepheline appears as smaller buff-colored or reddish idiomorphic grains. Aegirine occurs as thin $\mathrm{mm}$-sized needles forming wavy sheafs but without a pronounced lineation. The rock structure is that of an augen or flaser gneiss (cf. Shand 1947, also Sorensen 1974b, p. 401). Bright reddish-pink to pinkish purple eudialyte, a main constituent, appears as irregularly distributed eudialyte-rich patches (sizes varying from one to $4-5 \mathrm{~cm}$ ); the individual grains are anhedral to subhedral.

The type-II lujavrite (Lu II) is medium-grained and more paralleltextured than Lu I; eudialyte is usually a minor component.

$\mathrm{NeS} I$ is a leucocratic fine- to medium-grained rock with a trachytoid texture; aegirines are isolated, euhedral, $\mathrm{mm}$-sized prismatic to acicular grains. Accessories are eudialyte, fibrous aggregates of golden-brown astrophyllite (plus some lamprophyllite) and felty masses of a whitish acicular mineral (rinkite?).

$\mathrm{NeS} I I$ is a coarser-grained equivalent of NeS I, with less eudialyte and other accessories. 

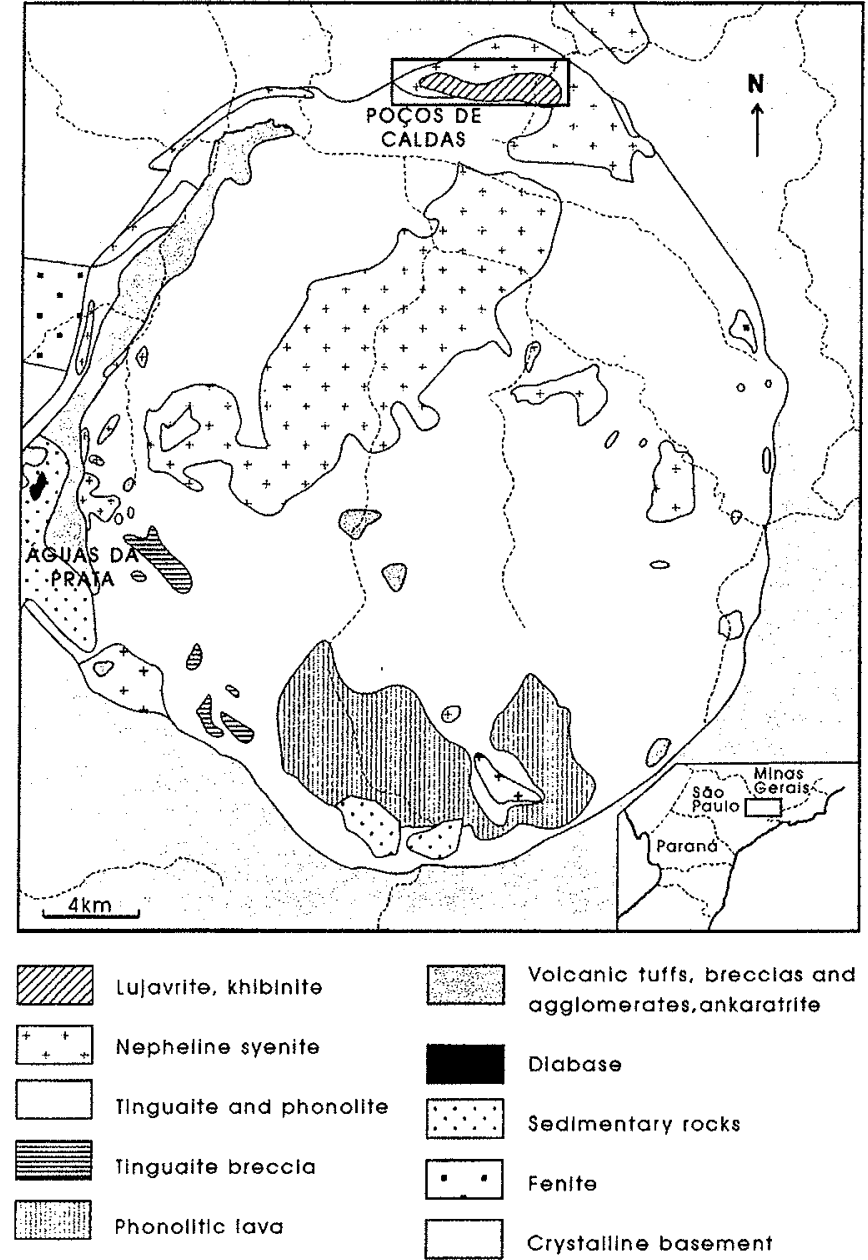

Figure I - Cieologic map of the Poģos de Caldas massif, states of São Paulo (SP) and Minas Gerais (MG), southeastern Brazil, after Ellert 1959. The area shown in figure $2 a$ is outlined.

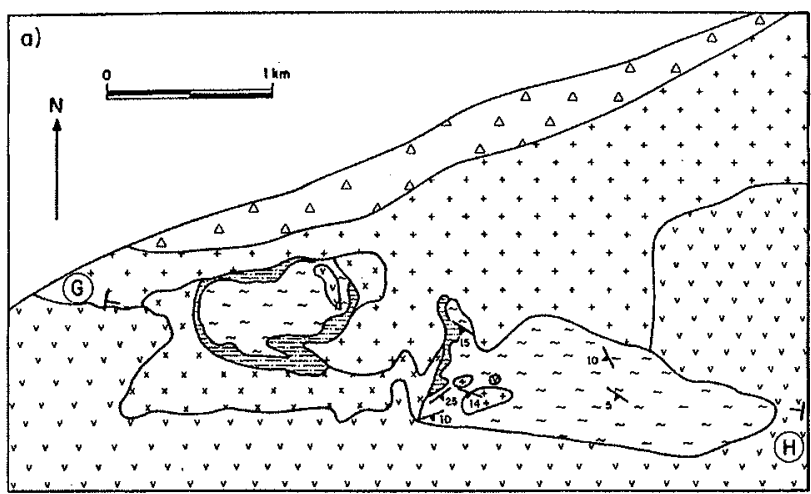

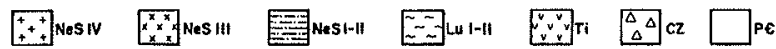

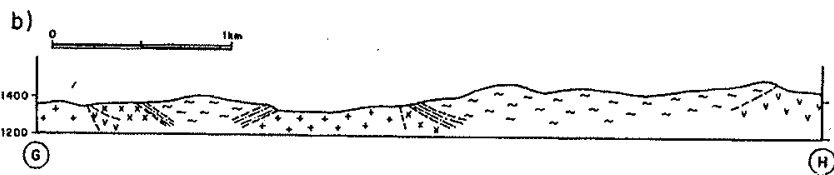

Figure 2 - a) Map of the two lujavrite occurrences, northern border of the massif (cf. Fig. 1). Contacts are approximate or inferred. CZ: contact zone, mainly supracrustal migmatitic-granulitic rocks of the Caconde Complex, cut by massive, fine-grained tinguaite dikes, veins, and lenses. Lu: lujavrite; NeS. nepheline syenites (for facies, see text); PC: Precambrian Caconde Complex; Ti: tinguaites. b) Geological section along line $G H$, based on maps of figures $2 a$ and $3 a$

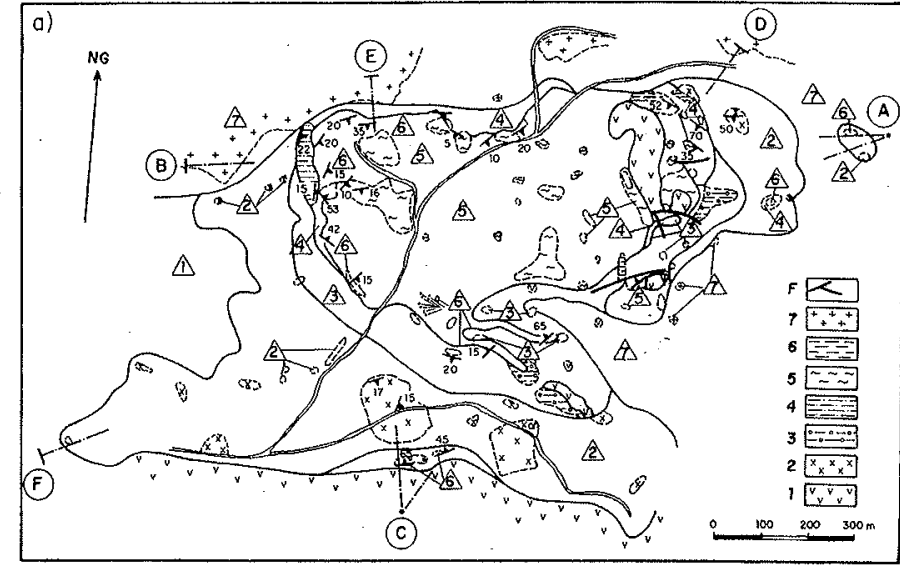

b)

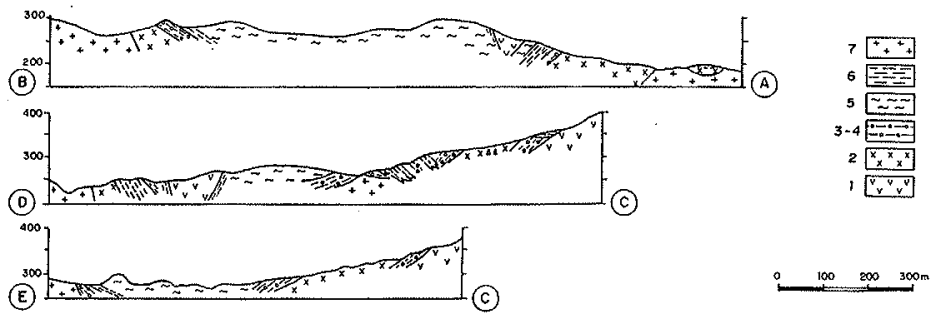

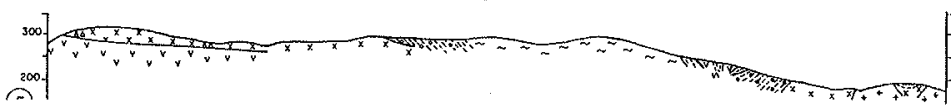

Figure 3-(a) - Detailed map of western lajavrite body, based on a 1:5000 plane-table survey. Dirt roads and trails marked with conventional symbols. Actual outcrops outlined by light dashed lines. Heavy continuous lines are observed or approximate contacts. Triangles identify aleas with many tinguaite xenoliths. Legend: 1: tinguaite; 2: khibinite, NeS III; 3: coarser trachytoid NeS II; 4: fine-grained trachytoid NeS I; 5: coarse lujavrite, La I; 6: fine-grained lujavrite, Lu III 7: NeS IV; F: faults.(b) - Geological sections across the western lujavrite body. Base for vertical scale is an arbitrary altitude of $300 \mathrm{~m}$ at the initial plane-table station (marked as heavy dot; actual altitude: $1350 \mathrm{~m}$ ). Legends as in Fig. 3a (3-4: both NeS I and II). The three segments of lujavrites and NeS I-II in profile CD are probably connected as parts of an eroded sheet; dips of contacts for this sheet, in the southern part of $C D$, have been exaggerated. (a)

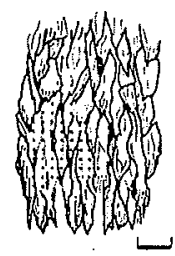

(c)

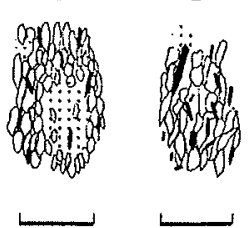

(b)

(f)

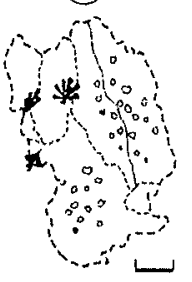

(e)

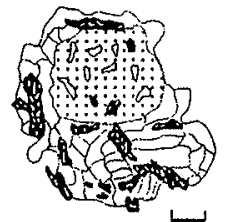

(f)

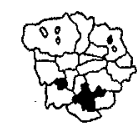

Figure 4 - Macroscopic aspect of the different phaneritic rock types. Aegirine in black, eudialyte-rich patches identified by dots, dominant feldspar and subordinate nepheline with no ornament. Bar represents one cm. a: Lu I; b: Lu II; $c:$ NeS I; d: NeS II; e: NeS III (khibinite); f: two varieties of NeSIV. 


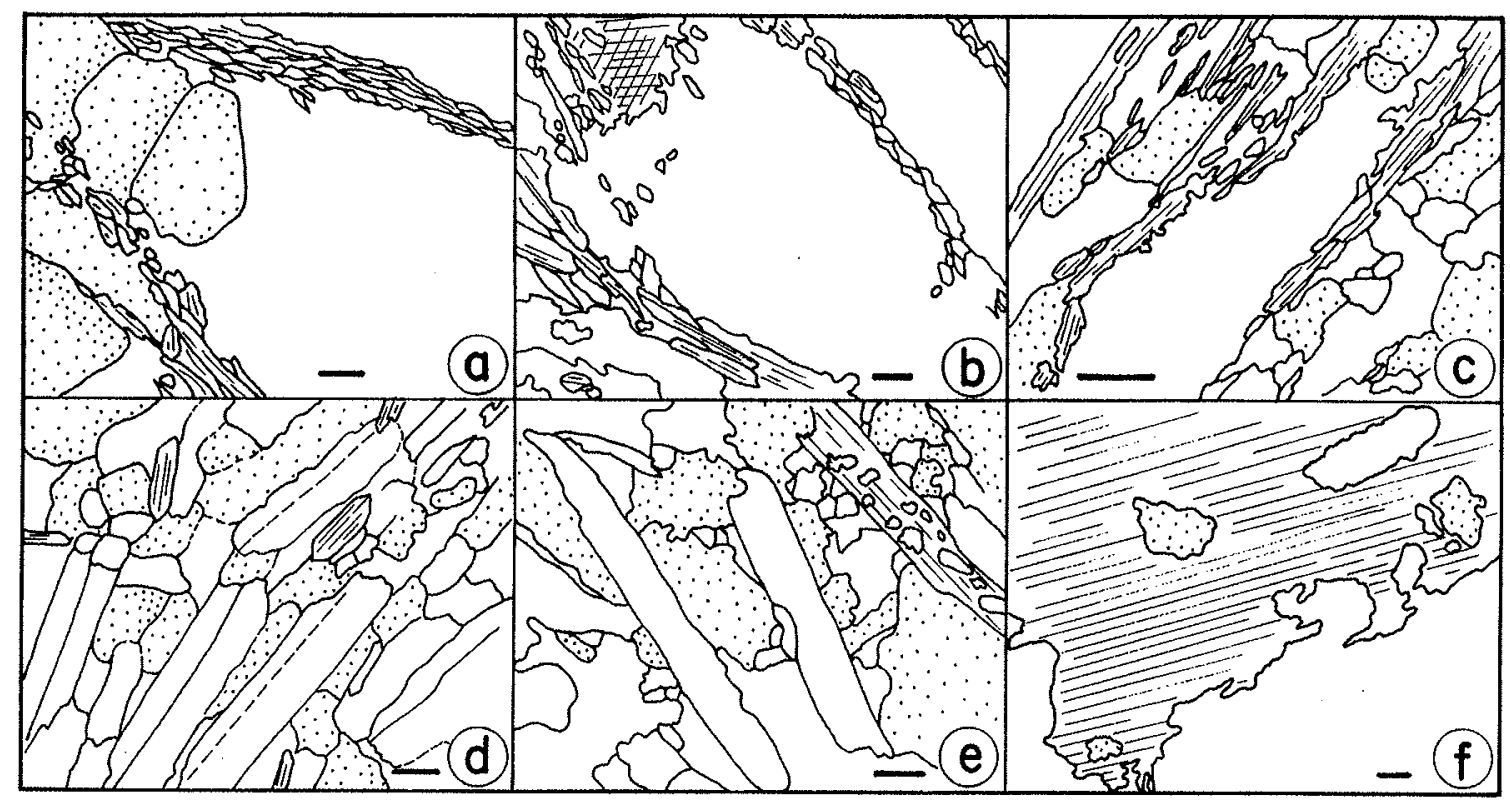

Figure 5 - Microscopic aspects of mapped facies. Bar represents $0.2 \mathrm{~mm}$. Dashes: aegirine; dots: nepheline; blank: alkali feldspar; a, b: eye-like felsic crystals or aggregates in Lu I, surrounded by continuous aegirine sheafs; in b, a large amphibole plate encloses aegirine needles; $c$ : Lu II, more paralell textured and leucocratic than Lu I; $d$ : medium-grained trachytoid texture of NeS I, with some small euhedral aegirine prisms; e: medium to coarse-grained trachytoid texture in NeS II; aegirine is already partly poikilitic; $f$ : large poikilitic grain of aegirine II in NeS III, enclosing smaller nephelines and alkali feldspars. Drawings from photographs.

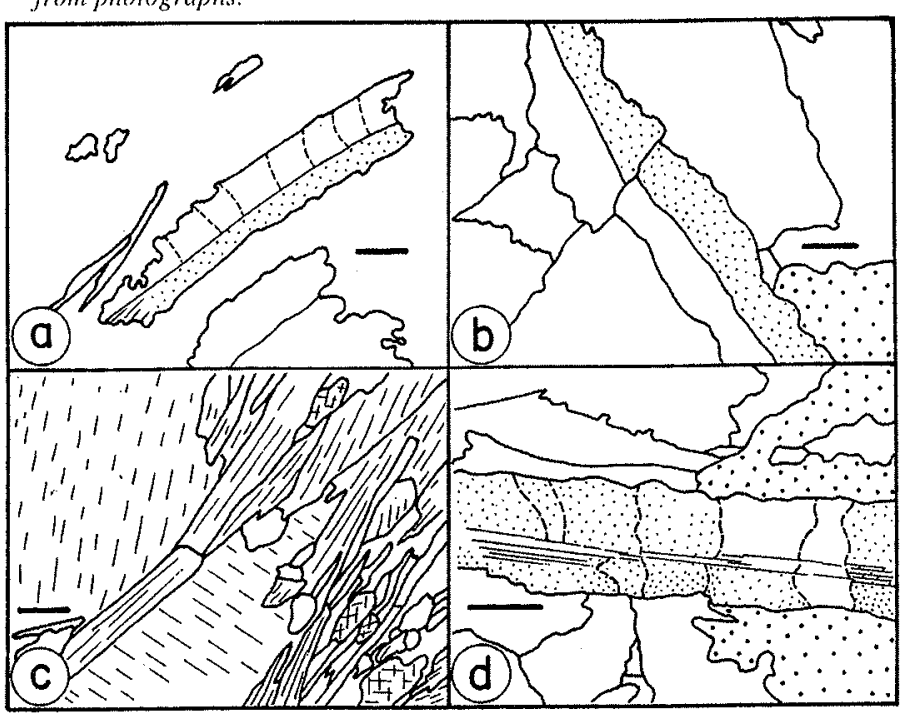

Figure 6 - Deformation features in NeS and lujavrites. Bar represents $0.2 \mathrm{~mm}$ Larger dots: nepheline; blanks, dots or short dashes: K-feldspar or albite; long dashes: aegirine. a bent crystals of alkali feldspar in Lu I, with incipient mortar struture, in a matrix of eudialyte, catapleitte and aegirine (not represented as single phases); $b$ : a blade-like alkali feldspar; broken and partly annealed at one of its ends (in. NeS III); $c$ : a long broken aegirine needle in Lu I (center of figure); $d$ : albite crystal with incipient mortar structure, in NeS I (outlined domains with marked differences in extinction). Drawn from photographs.

NeS III is a khibinite (Johannsen 1938, p.107-108, Gerasimovsky et al. 1974, p.214 ff). Textures are usually massive, sometimes foliated. Subidiomorphic whitish laths of $\mathrm{K}$-feldspar and small nepheline grains form a foyaitic fabric which includes large (up to $1-3 \mathrm{~cm}$ ) subidiomorphic poikilitic aegirines, with jagged borders and irregular terminal outlines. Eudialyte is concentrated in $\mathrm{cm}$-sized conspicuous patches. Strongly foliated varieties were also observed locally; they are either almost massive and hololeucocratic, or show a faint banding marked by an alternation of felsic and subordinate mafic layers.

$\mathrm{NeS} I V$ is a leucocratic grey massive rock, mostly coarse- to very coarse-grained. Subhedral K-feldspars (up to $3-4 \mathrm{~cm}$ ) poikilitically encloses round millimetric grains of nepheline (similar to the rischorrites, but without symplectitic intergrowths; Gerasimovsky et al.
1974, p.214). Irregular to acicular aegirine and platy biotites occur as isolated grains or aggregates. Astrophyllite and pink eudialyte are observed as accessories in samples close to the contact with khibinites; these minerals are late metasomatic phases, crystallizing from fluids derived from khibinite magmas, adding volatiles together with $\mathrm{Na}, \mathrm{Fe}$ and $\mathrm{Zr}$ to the NeS IV (cf. also Gualda 1998, Gualda \& Vlach 1996).

Pegmatite veins are found in $\mathrm{Lu} \mathrm{I}$, as irregular patches or lenses, rarely over 1 or $2 \mathrm{~m}$ in length, and in NSe III as dikelets within fractures (lenghts of a few $m$ to tens of $m$, thickness of up to $25 \mathrm{~cm}$ ).

Tinguaites (i.e., fine-grained to aphanitic greenish-grey equivalents of phonolites) are usually massive, aphyric or with some sanidine or nepheline phenocrysts. Tinguaite xenoliths, observed in all NeS, vary from small $\mathrm{cm}$-sized specimens to blocks of mappable dimensions (see Fig. 3).

Microscopic descriptions and mineral chemistry Some microscopic details of these rocks are shown in figure 5. Data on mineral chemistry are quoted in Table 2 (Ulbrich 1983, 1993, for rock chemistry, see Ulbrich 1984).

$L u I$ is, as all described NeS in this paper, a hypersolvus rock. Nepheline is distinctly euhedral or subhedral, usually much smaller than K-feldspar. It is a meso-potassic variety $(1.0$ to $2.0 \mathrm{~K}$ atoms per formula). Aegirine occurs as pleochroic, slightly zoned needles and slender prisms, with growth faces parallel to those of the felsic minerals. Frequently, the borders of microcline crystals are crowded with aegirine needles, leaving the central part of the grain with an eyelike appearance (Fig. 5). Minor arfvedsonite (about $1 \%$ ) is found as larger anhedral plates with inclusions of euhedral aegirine. Eudialyteeucolyte, restricted to the patchy areas, appears as interstitial grains typically with an irregular sector-zoning; it is frequently altered to catapleiite and other unidentified minerals. Main alteration phases of felsic minerals are analcime, natrolite and cancrinite (Table 1).

$L u I I$ (Table 1) is usually albite-bearing. The albite is very fresh, with irregular borders; its orientation, in general; cuts at a low angle the planar structure of the rock. Some minor arfvedsonite is observed as aegirine replacement. Another important mafic mineral is eudialyte. Accessory phases are astrophyllite, lamprophyllite, a rinkite-like mineral, pectolite, normandite and in minute proportions several unidentified minerals (cf. data in Gualda, 1998).

The textures of khibinites ( $N e S I I I$; Table 1 ) are partly foyaitic, partly hypidiomorphic inequigranular; K-feldspars are observed as primary euhedral laths, as irregular plates, and also as interstitial grains and overgrowths. Nepheline shows larger compositional variations than in lujavrites (Table 2). Aegirine is observed as variety I (subordinate, slightly pleochroic, occurring as small euhedral prisms), the predominant variety II (typical large poikilitic grains, with sector 
Table 1-Modal composition of lujavrites and associated rocks, Poços de Caldas.

\begin{tabular}{|c|c|c|c|c|c|c|c|c|c|}
\hline Facies & Lu I & Lu I & Lu II & $\mathrm{NeS} \mathrm{I}$ & $\mathrm{NeS}$ II & NeS III & NeS IV & NeS IV & NeS IV \\
\hline Sample number & $\begin{array}{l}\text { P46 } \\
(2)\end{array}$ & $\begin{array}{c}\text { P10/5 } \\
\text { (2) }\end{array}$ & $\begin{array}{c}\mathrm{P} 161 / 134 \\
\text { (2) }\end{array}$ & $\begin{array}{l}\text { P163 } \\
\text { (1) }\end{array}$ & $\begin{array}{l}\text { P164 } \\
\text { (1) }\end{array}$ & $\begin{array}{c}\mathrm{P} 47 / 173 \\
\text { (2) }\end{array}$ & $\begin{array}{c}\mathrm{P} 205 / 177 \\
\text { (coarse) } \\
\text { (3) }\end{array}$ & $\begin{array}{c}\mathrm{P} 49 \mathrm{~d} \\
\text { (medium) } \\
\text { (1) }\end{array}$ & $\begin{array}{c}\text { P131 } \\
\text { (medium) } \\
\text { (1) }\end{array}$ \\
\hline $\mathrm{K}$ feldspar & 38.2 & 33.8 & 46.0 & 49.3 & 49.2 & 59.0 & 59.1 & 64.4 & 58.0 \\
\hline Albite & & & 0.8 & 1.0 & 2.2 & & & & \\
\hline Nepheline ' & 24.8 & 17.2 & 24.9 & 27.7 & 30.2 & 18.6 & 25.1 & 27.0 & 27.4 \\
\hline Natrolite $^{2}$ & $\mathrm{tr}$ & 11.5 & $\operatorname{tr}$ & & 0.5 & & & & 2.6 \\
\hline Analcime $^{3}$ & $\operatorname{tr}$ & & 8.8 & 8.5 & 7.0 & $\operatorname{tr}$ & & & 0.4 \\
\hline Zeolites $^{4}$ & $\mathrm{tr}$ & & & $\operatorname{tr}$ & & & & & \\
\hline Sodalite & tr & & & & & tr & & & \\
\hline Cancrinite & & & $\mathrm{tr}$ & tr & & & 4.5 & 0.2 & \\
\hline Na-pyroxene & 27.3 & 27.4 & 17.1 & 8.6 & 5.8 & 10.1 & 8.7 & 5.6 & 7.6 \\
\hline Amphibole ${ }^{5}$ & 0.7 & 0.8 & & & & & & & \\
\hline Biotite & & & & & & & 0.7 & tr. & 0.2 \\
\hline Rinkite mineral & & $<0.1$ & $\mathrm{tr}$ & tr & tr & tr & & tr & \\
\hline Lamprophyllite ${ }^{6}$ & & & & $<0.1$ & & tr & 0.9 & $\mathrm{tr}$ & \\
\hline Eudialyte $^{7}$ & 7.6 & 3.7 & 1.6 & 4.1 & 0.9 & 7.9 & & & \\
\hline Catapleiite & $\mathrm{tr}$ & 3.8 & & & & & & & \\
\hline Opaques & $\mathrm{tr}$ & & & & & & & & 0.9 \\
\hline Others ${ }^{8}$ & 4.4 & 1.5 & 0.8 & 0.8 & 4.3 & 4.2 & 0.7 & 3.0 & 2.9 \\
\hline
\end{tabular}

1: some alteration included; 2: alteration of $\mathrm{Kf} / \mathrm{Ne} ; 3$ : mostly alteration of $\mathrm{Ne} ; 4$ : analcime + natrolite; 5 : mostly arfvedsonite; 6: lamprophyllite and astrophyllite; 7: eudialyte-eucolyte; 8: sphene, fluorite, unidentified species, also opaques.

In parenthesis, number of counted thin sections.

Table 2 - Textures, color index and mineral chemistry of lujavrites and associated rocks, Poços de Caldas.

\begin{tabular}{|c|c|c|c|c|c|c|}
\hline & Lujavrite I (Lu I) & Lujavrite II (Lu II) & $\mathrm{NeS} \mathrm{I}$ & \begin{tabular}{|l|} 
NeS II \\
\end{tabular} & NeS III (khibinites) & NeS IV (grey Nes) \\
\hline $\begin{array}{l}\text { Texture } \\
\text { Grain size } \\
\text { Color Index }\end{array}$ & $\begin{array}{l}\text { "Gneissic" fabric } \\
\text { Coarse to medium } \\
>33\end{array}$ & $\begin{array}{l}\text { Parallel-textured } \\
\text { Medium to fine } \\
-10-25\end{array}$ & $\begin{array}{l}\text { Trachytoid } \\
\text { Fine-medium } \\
-10-15\end{array}$ & $\begin{array}{l}\text { Trachytoid } \\
\text { Medium } \\
<12\end{array}$ & $\begin{array}{l}\text { Massive (foyaitic) } \\
\text { Coarse-medium } \\
15-25\end{array}$ & $\begin{array}{l}\text { Massive (foyaitic) } \\
\text { Coarse to medium } \\
<11\end{array}$ \\
\hline KF:Ne ratio & $\leq 2: 1$ & $\leq 2: 1$ & $\leq 2: 1$ & $<2: 1$ & $-2: 1 *$ & $>2: 1$ \\
\hline KF Or:Ab:An & $86-95: 13-5:-0.2$ & $84-88: 16-12:<0.2$ & $84-86: 14-15.5:<0.2$ & As in NeS I & $88-99: 13-1:<0.2$ & $\begin{array}{l}94-98: 6-1:<0.2 \text { up to Or } \\
100\end{array}$ \\
\hline Fe $203 \%$ & $0.54-0.6$ & $1.5-2.0 \%$ & & & & \\
\hline Albite Ab:An & & $>99:<1$ & $>99:<1$ & As in NeS I & & \\
\hline $\begin{array}{c}\mathrm{Ne} \quad \mathrm{Ne}: \mathrm{Ks}: \mathrm{Qz} \\
\mathrm{Fe} 2 \mathrm{O} 3 \%\end{array}$ & $\begin{array}{l}70-73: 25-23: 3-5 \\
0.4-0.6\end{array}$ & $\begin{array}{l}74: 19-21: 6-7 \\
1.5-2.0\end{array}$ & $\begin{array}{l}73-7419-21: 5-8 \\
0.9-3.3\end{array}$ & $\begin{array}{l}\text { As in NeS I } \\
\text { As in NeS I }\end{array}$ & $\begin{array}{l}72-74: 21-27: 1-5 \\
0.3-2.5\end{array}$ & $\begin{array}{l}73: 24-26: 1-3 \\
0.5-2.0\end{array}$ \\
\hline Acgirine Di:Hd:Ac & $\begin{array}{ll}\text { C } & 6-9: 12-16: 68-75 \\
\text { B } & 1-4: 2-9: 73-88\end{array}$ & $\begin{array}{l}\text { C } 8-12: 17-22: 62-68 \\
\text { B } 6-9: 8-14: 69-78\end{array}$ & $\begin{array}{l}\text { C } 10: 17: 65 \\
\text { B } 5: 16: 73\end{array}$ & $\begin{array}{l}\text { C } 8-11: 11-18: 63-71 \\
\text { B } 5: 11-15: 73-78\end{array}$ & $\begin{array}{l}0-2: 2-4: 81-85 \text { (no } \\
\text { color) to 4-6:13-21:62- } \\
70 \text { (green) })^{* *}\end{array}$ & $0-5: 8-15: 70-76^{* * *}$ \\
\hline $\begin{array}{ll}\text { Arfvedsonite } \mathrm{MnO} \% \\
\text { TiO2 } \\
\text { Biotite } & \mathrm{MnO} \% \\
& \text { TiO2 \% } \\
\end{array}$ & $\begin{array}{l}3.4-6.0 \\
\text { up to } 1.5\end{array}$ & As in Lu I & & & As in Lu I & $\begin{array}{l}2.0-5.0 \\
2.3-4.1 \\
\end{array}$ \\
\hline
\end{tabular}

C. core, B: border of pyroxenes. KF: K feldspar: Ne: nepheline. Ne, Ks, Qz: nepheline, kalsilite and excess quartz components in Ne (weight \%). Di, Hd, Ac: diopside, hedenbergite and acmite C. in sectol-zoned main pyloxene (type II, see text). *** (NeS IV): medium-green aegirine (lighter colored aegirines have different composition, cf. Ulbrich 1983).

and irregular oscillatory zoning; Fig. 5) and the hydrothermal late aegirine variety III (strongly pleochroic, parallel or radiating fibers). Sporadically, arfvedsonite replaces aegirine. Eudialyte is sector-zoned and interstitial to the main minerals (although partly idiomorphic) and partially altered to catapleiite. Analysis of eudialyte and other rare silicates can be found in Gualda \& Vlach (1996). A few grains of small $(0.2 \mathrm{~mm})$ euhedral sodalite are enclosed within $\mathrm{K}$-feldspar. The most frequent accessory minerals are a rinkite mineral, acicular astrophyllite and anhedral to subhedral sphene, a late strongly colored violet fluorite, and several unidentified rare-metal silicates. Alteration is widespread: interstitial cancrinite, replacing both feldspar and nepheline, and analcime and platy natrolite are secondary minerals.

$\mathrm{NeS} I$ and $\mathrm{NeSII}$ are very similar trachytoid rocks (Table 1; Fig. 5). Nephelines show a large $q z$ number (Table 2). The aegirines are usually idiomorphic prisms; in NeS II, the largest aegirine prisms are filled with inclusions (transition to NeS III). Laths of albite are present in both rocks. Eudialyte is less frequent in NeS II. Additional phases in $\mathrm{NeS} I$ are astrophyllite and a rinkite mineral, together with some unidentified subordinate species. Secondary analcime and natrolite are frequent. Some analcime is probably a primary mineral (for other minerals, cf. also Gualda, 1998).

NeSIV shows a K-feldspar/nepheline ratio usually well over $2: 1 . \mathrm{K}$ - 
feldspar encloses small euhedral to subhedral nepheline (Fig. 4); nepheline is also in part interstitial. Mafic minerals are mainly clusters of zoned aegirine with minor biotite (Fig. 4); biotites are irregularly zoned (Fe biotites with a strong yellowish-brownish pleochroism, Mg biotites with a yellowish uniform color).

Deformation Signs of deformation are observed in NeS I, II and III, and especially in lujavrites, but are restricted to individual grains and do not affect the rock as a whole (see broken or bent minerals in Fig. 6).

Order of crystallization and the fluid-rich nature of the magmas The observed textures show that in these agpaitic rocks nepheline is the first main mineral to crystallize, either together with $\mathrm{K}$ feldspar, or shortly before it. Aegirines, also mostly magmatic minerals, crystallize later; the exception are the smaller euhedral typeI aegirines in khibinites and the pyroxene prisms in NeS I and II, which apparently crystallized early in the magmas. The frequently observed face-to-face contact between these three minerals suggests the coexistence of all three phases at a late, but still magmatic stage. They were probably drawn together as "cumulates" by dynamic processes. Interstitial growth of aegirine and feldspar is important only in khibinites and to some extent in coarse lujavrites. It is the result of either intercumulus crystallization (e.g., feldspar borders in NeS III) or, as in the case of fibrous aegirines, of late-magmatic to deuteric addition of material, with metasomatic introduction of $\mathrm{Fe}, \mathrm{Na}, \mathrm{F}$, etc. Other important mafic minerals (eudialytes in all NeS; arfvedsonite as an accessory phase in Lu I) are late and in part reaction-replacement phases (arfvedsonite). Albite laths are found only in Lu II, NeS I and NeS II, and were formed by exsolution, reordering and recrystallization of K-feldspars, aided probably by the addition of $\mathrm{Na}$.

This sequence of formation corresponds to the "agpaitic order of crystallization" in nepheline syenites, with formation of early nepheline and K-feldspar and late pyroxene, in contrast to the "miaskitic order" with early mafic minerals (after Kogarko \& Gulyaeva 1965, as cited in Kogarko 1974).

The original magmas were very mobile and probably rich in several volatiles, later concentrated in deuteric fluid phases, a feature reflected in the composition of some minerals $(\mathrm{F}$ in fluorite and arfvedsonite, $\mathrm{Cl}$ in eudialyte, $\mathrm{H}_{2} \mathrm{O}$ in alteration minerals, $\mathrm{CO}_{2}$ also in some cancrinites; cf. also Sorensen 1974a, Kogarko 1974, Sorensen \& Larsen 1978).

Twinning patterns of K-feldspars The K-feldspars in the described NeS show a typical triclinic "multiple twinning" (Ulbrich, 1983,1993 ), previously described in some other NeS (Mackenzie 1954, Smith \& McLaren 1983). The pattern resembles that of a "chessboard" albite twinning. Several twinning types are recognized, characterized by increasing Al-Si ordering (Ulbrich 1983, 1993): a) in incipient twinning, only small cloudy veins and patches are twinned, irregularly distributed in an otherwise monoclinic K-feldspar; b) in poor twinning, most of the grain is taken over by the turbid twinned areas, with subordinate clean monoclinic patches; c) in good twinning, the whole K-feldspar is twinned and turbid; d) the next step is a very good twinning, in which the entire crystal is clear, with well-developed twin individuals or domains (akin to the "tiled microclines" of Smith $\&$ McLaren 1983). Several of these twinning patterns can coexist in any rock, or even in a thin section, but one of them is usually the predominant type.

The twinning pattern is, in general, well-developed along the strained areas of the K-feldspar host that surround both albite laths and the microperthitic albite, although it is not restricted to these areas. The coarser Lu I and NeS III show predominantly the better developed twinning ("type b"); incipient ("type a") and "type b" twinning are mostly found in the finer-grained Lu II, NeS I and II, together with albite laths, formed by exsolution-recrystallization of their K-feldspar host. Good twinning ("type c") is also found in NeS IV (Ulbrich, 1993).

Geothermometry The nepheline and the nepheline-feldspar reequilibration geothermometers (Hamilton \& McKenzie 1960, Hamilton 1961, Powell \& Powell 1977) yield several estimates for the magmatic crystallization temperatures of the Poços de Caldas rocks, for a $\mathrm{H}_{2} \mathrm{O}$ pressure up to about $1 \mathrm{~kb}$ (Ulbrich $1983,1985,1993$ ). Experimental figures (Sood 1981) show that lujavrite magmas are very cold, with a solidus close to $400^{\circ} \mathrm{C}\left(1 \mathrm{~kb} \mathrm{H}_{2} \mathrm{O}\right.$ pressure), or even below it, although the liquidus is near $850^{\circ} \mathrm{C}$ (with $\mathrm{K}$-feldspar as the liquidus phase); temperatures for khibinitic magmas are probably quite similar. Miaskitic magmas, on the other hand, crystallize completely at about $620^{\circ} \mathrm{C}(1 \mathrm{~kb})$, with a liquidus temperature around $820^{\circ} \mathrm{C}$. For Lu II and NeS I-II, the recorded magmatic re-equilibration temperatures (RT) between the two felsic minerals are $580-600^{\circ} \mathrm{C}$, and around 540$500^{\circ} \mathrm{C}$ for the coarser-grained Lu I and khibinites, or even lower. NeS IV yields $\sim 500^{\circ} \mathrm{C}$ as its lowest RT.

STRUCTURE A sketch map and geologic sections of the two lujavrite outcrops are shown in figure 2 .

Western body Lu I is the facies found at the center of this body, passing into the border facies Lu II (Fig. 3a, 3b). Two small sheets of projecting $\mathrm{Lu}$ II can be found along the $\mathrm{S}$ contact, and some metersized Lu II outcrops appear within tinguaites, spatially unconnected to the main Lu I (Fig. 3a). Lu II thickness varies from about $2-3 \mathrm{~m}$ to as much as $20 \mathrm{~m}$ (profiles BA and EC, Fig. 3b). In one instance, a few Lu I veins cut the Lu II foliation at a very low angle (Fig. 7a). NeS I and $\mathrm{NeS}$ II form an outer shell to the lujavrites, with very rapid passage of one into the other; NeS I is from 4 to $15-20 \mathrm{~m}$ thick, NeS II is up to 50 $m$ thick (Fig. 3b). NeS II grades rapidly into khibinite. NeS I and NeS II structures are concordant with the Lu II foliations.

The shell-like feature of the structure is emphasized by the sequence Lu I- Lu II - NeS I - NeS II, with NeS III on the outside; some facies may be missing (see sections in Fig. 3b). NeS III, not in direct contact with lujavrites at the present level of exposure, probably thins out at the root zone (section FA, Fig. 3b)

The planar structures of Lu I go from subhorizontal to the moderate or even steep concordant dips of the Lu II and NeS I-II foliations (Fig. 3a). Observations along some profiles (e.g., line FA, Fig. 3b) indicate that the successive sheets are flatter towards the outside (so, NeS III wedges out towards the lujavrites and may in fact be very thin, or even

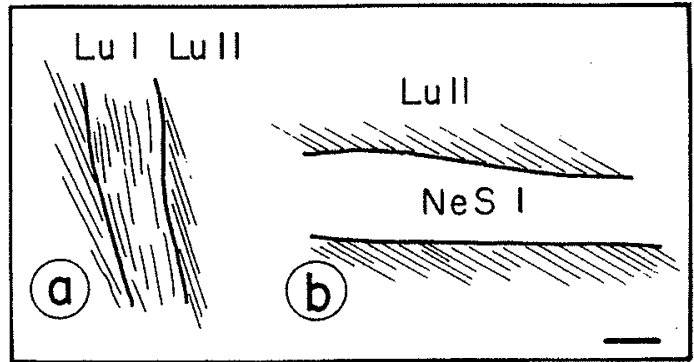

Figure 7 - (a) - Lu l vein cutting Lu II foliation at a slight angle (oucrop at a Lu I patch, separated from the main we stern body by a small fault; Fig. 3 a), (b) - NeS I cutting as a small dikelet the Lu. II foliation (outcrop at westem end of eastern lujavrite body; Fig. 2a). Scale bar represents $5 \mathrm{~cm}$. Drawn from photographs.

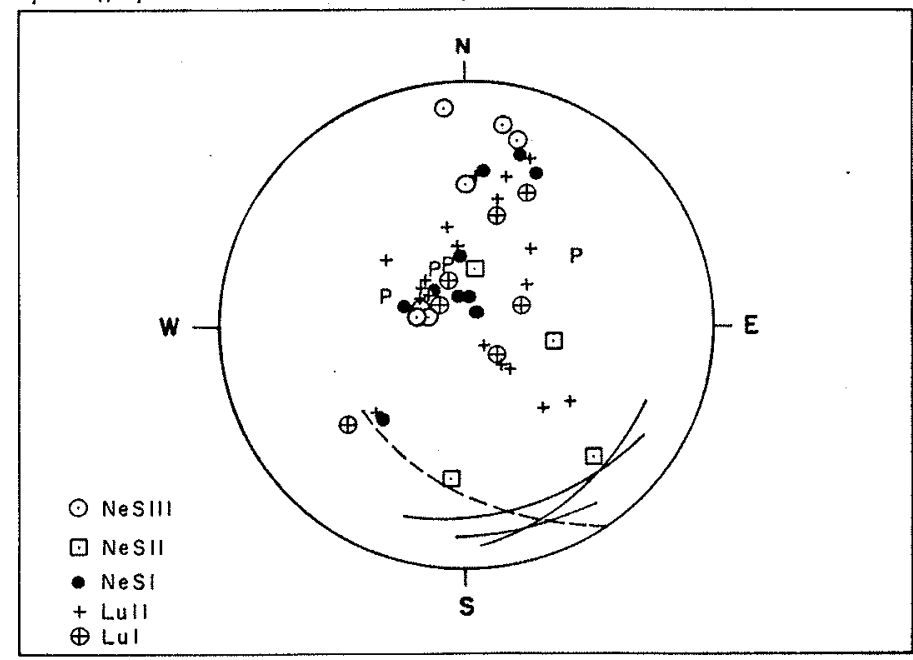

Figure 8 - Pole diagram of fluidal structures (Schmidt's net, lower hemisphere). Full and dashed greater circles represent the position of pegmatite dikes $(P)$ in NeS $I I$, intruded along two conjugate fracture planes. 
absent, below them). As a result, the lujavrites and associated rocks may have a maximum thickness of about 80 to $100 \mathrm{~m}$ at the root zone (see section FA, Fig. 3b). The structure is that of a flat asymmetric saucer, with its major axis trending E-W and steeper dips of foliations to the $\mathrm{E}$ (Fig. 3a). Poles of foliation emphasize the overall concordant attitudes (Fig. 8). Pegmatite veins within NeS III are preferentially located along two conjugate fracture systems (Fig. 8).

Foliated and banded structures within khibinites are developed only locally, with a thickness varying from decimeters to several meters and extensions of up to $10 \mathrm{~m}$; rather abruptly, massive khibinites take their place. On the other hand, the structural attitude of these foliations shows no general relationship with the overall geometry of the entire body. A minor banded and foliated leuco-syenite structure (Fig. 9) is found at the western margin of this body, intrusive into NeS IV (see the NeS III-IV contact in Fig. 3a) this foliated NeS III is surrounded, and in part clearly invaded, by massive khibinite, which is also intrusive into NeS IV. These observations suggest that the khibinite fluid-rich magmas were very mobile and subjected to local controls that generated foliated structures (e.g., in minor convection cells), in part destroyed and invaded by subsequent remobilization of the remaining liquid portions of the magma chamber.

The present structural interpretation for these lujavrite bodies differs from that proposed by Bushee (1974), who mapped all the cited $\mathrm{NeS}$ as varieties of a single rock type, with the exception of the lujavrites.

Eastern body The eastern lujavrite body measures about $2 \times 0.75$ $\mathrm{km}$. The area is deeply weathered and covered mostly by talus, vegetation and coffee plantations. To the $\mathrm{N}, \mathrm{NE}$ and $\mathrm{S}$, the lujavrites are in contact with tinguaites and NeS IV (see also map in Bushee, 1974), showing planar subhorizontal structures (dips up to $10-15^{\circ}$ ). Lujavrite outcrops are missing along the southern lujavrite-tinguaite contact, but the straigth trace suggests that it is probably vertical. Lu II is observed only along the irregular western edge of this body, accompanied on the outside by NeS I and NeS II and finally by khibinites. In a few exposures on this western edge the relationships indicate intrusion of NeS I into Lu II (Fig. 7b).

AGE RELATIONSHIPS Tinguaites crystallized as the oldest rocks, since they are present as xenoliths in lujavrites and in the rest of the NeS (including NeS IV).

In the western body, the five agpaitic facies (Lu I-II, NeS I-II-III) are related to each other in a predictable shell-like structural pattern, constituting a single intrusive unit. NeS III is also intrusive into the miaskitic to intermediate NeS IV. In some cases, NeS I-II present a cross-cutting relationship in contacts with $\mathrm{Lu}$ II (Fig. 7b) and Lu I is also seen as veins that cut the Lu II foliation (Fig. 7a); these features are interpreted as the equivalent of "synplutonic" dikes. The sequence of intrusion is thus tinguaite $\rightarrow \mathrm{NeS} \mathrm{IV} \rightarrow$ lujavrites and other agpaitic facies. The same pattern can also be applied to the eastern lujavrite body.

THE STRUCTURAL RELATIONSHIP BETWEEN THE EASTERN AND WESTERN LUJAVRITE BODIES The lujavrite in the eastern body seems to lie directly in contact with the tinguaites that formed the floor of the former magma chamber. The

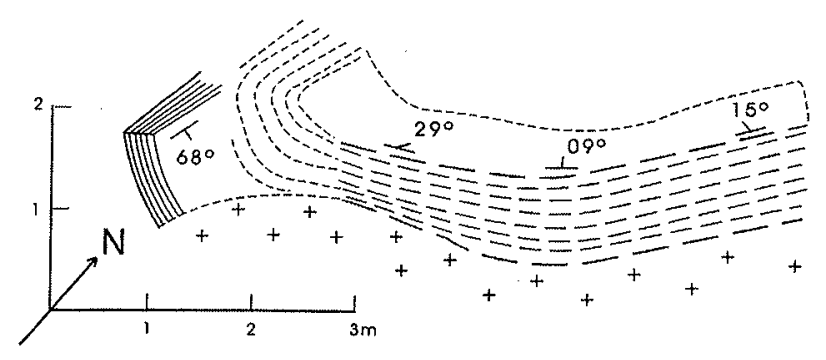

Figure 9 - Banded and laminated leuco-syenite outcrop, within khibinites (intrusive into NeS IV), at the western contact of the western khibinite body (cf. Fig. 3a) western body shows around its central lujavrite a well-developed "halo" of khibinites (NeS III), which however thins out under the lujavrites (e.g., profile FA in Fig. 3b).

The two lujavrite bodies are not directly connected at the present level of erosion (Fig. 2), and they probably crystallized in different parts of the same magma chamber or even in two unconnected separate small magma chambers. In any case, the parental magmas are khibinitic and are probably related to the other agpaitic Poços de Caldas intrusions showing eudialyte as their identifying mineral (e.g., Ulbrich \& Ulbrich 1992). All these agpaitic magmas clearly originate at depth and were emplaced as late separate intrusions, as shown by geologic relationships.

MECHANISM OF EMPLACEMENT In the Poços de Caldas occurrences, the mechanism of emplacement has to explain the following aspects (Ulbrich 1983, Ulbrich 1984):

a) the structural relationship between all five facies of lujavrites and khibinites and the origin of the magmatic foliations, as well as the sequence of intrusion-mobilization (cf. Figs. 3, 7);

b) the lack, or relative paucity, of eudialyte, aegirine and other mafic minerals in NeS I and II;

c) the strong indications of recrystallization and reordering shown in all five facies (e.g., the different twin patterns and Al-Si ordering in K-feldspars; albite laths only in Lu I, NeS I and II; etc.)

The actual structures at their emplacement site cannot be explained in terms of simple in-situ crystal settling controlled by density currents or gravity (e.g., inclined structures in Lu II, NeS I and II; Figs. 2, 3).

The proposed emplacement mechanism is envisaged as a continuous process during the injection of strongly agpaitic, fluid-rich khibinitic magmas (not mushes, see Deformation, above) that combines forceful emplacement with compaction and the formation of a cap of crystallizing lujavrite, all the while accompanied by lateral spreading and enlargement of the original magma chamber (Fig. 10a, b, c). The initially mostly liquid khibinite magma entered through a central channel, under a local stress regime leading to sill formation ( $s_{3}$ vertical, Fig. 10a), and was trapped under a crystallized but still very hot tinguaite cover. This magma was enriched in volatiles and also in $\mathrm{Na}, \mathrm{Fe}, \mathrm{Mn}$, and some rare metals, leading to conditions whereby $\mathrm{K}$ feldspar (and nepheline) were the liquidus phases, with somewhat later magmatic crystallization of the rather abundant mafic minerals (aegirine, also eudialyte). Around this initial blob, a contact envelope was formed, not cooler but certainly more viscous than the core, on account of some volatile loss. In the inside, volatiles were held concentrated, together with the elements they could transport ( $\mathrm{Fe}, \mathrm{Zr}$; $\mathrm{Na}$, rare metals). The kinetic conditions for the crystallization of a coarser Lu I at the core of the magma blob were thus created, in contrast to the marginal Lu II.

The khibinite magma continued its intrusion, under and alongside the lujavrite cap, in contact with tinguaite to the S (with NeS IV, to the $\mathrm{N}$ and $\mathrm{W}$ ). The effect is threefold: a) a mostly lateral expansion and significant enlargement of the original magma chamber; b) a forceful but slow horizontal flattening of the crystallizing lujavrite cap (now a mush) together with its compaction, and c) the formation of Lu II as well as NeS I-II as a more viscous magmatic contact envelope around Lu I. The compaction is certainly coupled with the migration and loss of interstitial magmas, together with the rearragement of the crystallizing minerals into oriented patterns, both in the more viscous envelope as well as in the central lujavrites (Lu I; Fig. 10B).

The re-equilibration temperatures $\mathrm{RT}$, taken as indications of the lower crystallization ranges, show that Lu I and probably also NeS III (RT about 500-540 ${ }^{\circ} \mathrm{C}$ ) were still at least partly liquid under conditions where the volatile-depleted Lu II and NeS I-II (RT of 580$600^{\circ} \mathrm{C}$ ) had already crystallized (cf. references, above). These contact facies were thus subjected to an additional "cooking" by the cooling central Lu I and the surrounding khibinites, and exposed to the passage of some percolating deuteric fluids. These conditions favoured the exsolution of albite (both as microperthites and laths) in Lu II and NeS I - II by reconstitution of their K-feldspars, probably with $\mathrm{Na}$ addition by percolating fluids (some comments on the behavior of interstitial magmas are put forward in Gualda, 1998).

The conversion of disordered K-feldspars to microcline in Lu I and $\mathrm{NeS}$ III started under solidus conditions at a lower temperature (cf: Geothermometry) than in Lu II and Nes I-II; there is no indication that 
microcline formed at a magmatic stage in the coarse rocks. It is not clear, however, why the multiple twinning is better developed in the coarser-grained rocks, while Lu II and NeS I-II show mostly incipient twinning. The exsolution of albite from the original monoclinic alkali feldspar in Lu II and NeS I-II may not favor the concomitant or later "microclinization" process, or perhaps the incipient twinning is the type that is achieved at higher temperatures in these contact facies, later to be stopped simply by unfavourable kinetic conditions.

The initial upwelling of the magma occurred along a curved or straight vertical fracture path (Fig. 2a), possibly representing the equivalent of a late ring fracture, before spreading laterally into the present emplacement site.

The whole process took place under a lithostatic and maximum $\mathrm{H}_{2} \mathrm{O}$ pressures of up to $1 \mathrm{~kb}$ (Ulbrich 1984). The overall initial intrusion temperatures ( $>650$ or $>700^{\circ} \mathrm{C}$; Sood, 1981) were certainly higher than the recorded geothermometric RT figures; the passage from magmas into mushes occurred mainly at the emplacement site. These conditions place the in situ crystallizing "mushes" into the field of ductile behavior, thus making it easier to produce melt extraction, compaction, and structural re-arrangement of already formed minerals. Brittle deformation (Fig. 6) is kept at a minimum.

It is tempting, but probably misleading, to compare the cited stratigraphy with the one that appears at Ilímaussaq (Sorensen 1970 , Ferguson 1970, Paslick et al. 1993). The Poços de Caldas khibinites would then correspond, as the lowermost unit, to the Ilímaussaq bottom kakortokites, the lujavrites representing the middle horizon. But there are no direct or indirect structural or mineralogical indications that a rock such as the Ilímaussaq upper naujaite (=sodalite $\mathrm{NeS}$ ) flotation unit ever existed on top of the Poços de Caldas lujavrites: on the one hand, the differences in geological setting and thickness are very large between the two occurrences (e.g., Larsen \& Sorensen 1987, Bailey \& Gwozdz 1994), while sodalite, on the other, is a rare mineral in the Poços de Caldas NeS.

\section{A PETROGRAPHIC AND STRUCTURAL COMPARISON} WITH ROCKS FROM OTHER OCCURRENCES The Lovozero lujavrites, with an age of $290 \mathrm{Ma}$, are more leucocratic (as little as 15\% mafics; Fig. 11) and some are rich in amphibole (black lujavrites); the main accessory phases are lamprophyllite, murmanite, loparite, ramsayite, rinkite-rinkolite, villiaumite, sphene and apatite, and sodalite is also an essential primary mineral (Vlasov et al. 1966, Sorensen 1970). The Ilímaussaq lujavrites, age of $1130 \mathrm{Ma}$, are divided into green (aegirine) and black (amphibole) varieties, and albite and sodalite as important minerals; also cited are streenstrupine, aenigmatite, monazite, lovozerite, ussingite, villiaumite, pyrochlore, and others (Sorensen 1970, Ferguson 1970, Paslick et al. 1993, Blaxland et al. 1976, 1978). Minor minerals found in the Diablo Plateau lujavrite, belonging to the Trans-Pecos Cenozoic alkalic province of Texas and Arizona (ages of $35 \mathrm{Ma}$; Potter 1996), are aenigmatite, biotite and fayalite (Barker et al. 1977, Barker 1987).
Eudialyte may be absent from some lujavrites, or present only in minor amounts (e.g., Shand 1929, Vlasov et al. 1966). The average Illimaussaq kakortokite is similar to the Poços de Caldas lujavrite (cf. Ferguson 1970; Table 1, Fig. 11).

The type khibinite from Khibina (Johannsen 1938; age of $365 \mathrm{Ma}$ cited in Zaitsev 1996) is modally as variable as the Poços de Caldas equivalent rocks, especially in their KF-Ne ratios; some Khibina specimens may be poor in eudialyte, while others show biotite, alkali amphibole and aenigmatite (e.g., Sorensen 1970).

Similarities, as well as differences, are found in the structural setting. In cross-sections, the Lovozero lujavrites are depicted as a funnel-shaped structure with subhorizontal fluidal foliation, dipping gently to moderately towards the center; they are separated on structural grounds into two units, considered to be late intrusions (Sorensen 1970, Gerasimovsky et al. 1974). The Ilímaussaq lujavrite is located between the bottom layered kakortokites and the naujaite flotation cumulate, and has been interpreted as the reinjected residue formed from a large agpaitic magma batch after the extraction of the naujaite and kakortokite components (Ferguson \& Pulvertaft 1963). Cumulate processes have also been proposed to interpret the formation of the Ilímaussaq lujavrites (Upton 1974, p.231, Larsen \& Sorensen 1987), to the extent that the basal aegirine lujavrites are defined as orthocumulates (Bailey \& Gwozdz 1994); some geologic relationships suggest that compaction must have played a significant role in controlling texture and structure at their final emplacement site (Ferguson \& Pulvertaft 1963, Sorensen 1974a, p.44). The Pilansberg lujavrite (age of $1250 \mathrm{Ma}$ ) is restricted to some localized outcrops within the ring of "green foyaite" (Shand 1929, p.112); newer work by Retief (cited in Mathias 1974, p.196) shows that these rocks constitute moderately to steeply dipping sheets. The Trans-Pecos (SW Texas) lujavrites, on the other hand, appear within small alkaline intrusions in SW Texas, intermittently injected as a magmatic mush, since early lujavrite foliations are disturbed by later ones (Barker et al. 1977), at pressures probably lower than those registered for the other lujavrite occurrences.

The Texas occurrence suggests that magmas akin in composition to lujavrites may have existed and were emplaced either as mushes (as claimed by Barker et al. 1977) or, alternatively, as more liquid mixtures (e.g., Larsen \& Sorensen 1987, Bailey \& Gwozdz 1994), with residual melt extracted during a later compaction episode. In Poços de Caldas, a more complex intrusion mechanism for the formation of these rocks is favored (Fig. 10). The information on other occurrences (Ilímaussaq, Lovozero, Pilansberg) can be reinterpreted, suggesting that magma emplacement coupled with a compaction episode was probably the main responsible factor determining the final lujavrite fabric

Acknowledgements The authors thank the Brazilian agencies FAPESP and CNPq for support for field and laboratory studies, and $\mathrm{E}$ Bagnoli for help during mapping. To two anonymous referees of $R B G$ for the critical review and suggestions to the manuscript.

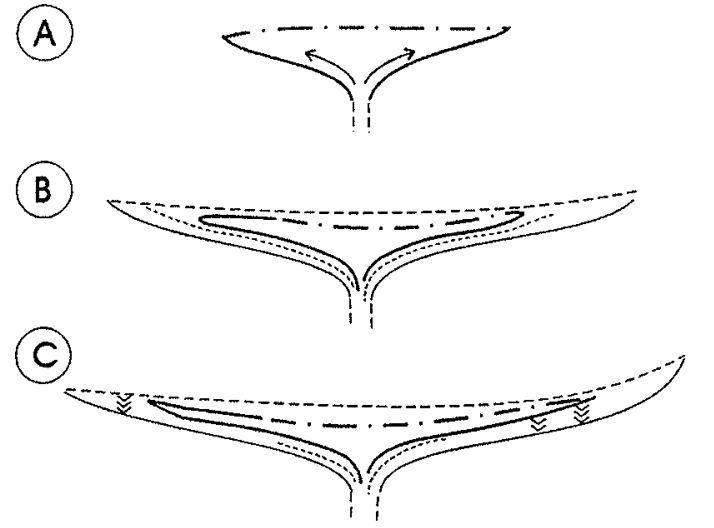

Figure 10 - A schematic representation of the sequential mechanism of intrusion, western lajavrite body. The black lines indicate the position of the Lu II envelope with a Lu I core, surrounded by spreading khibinite magma. Outlined throughs represent the sites of smaller convection cells, generating igneous foliation. For explanation, see text.

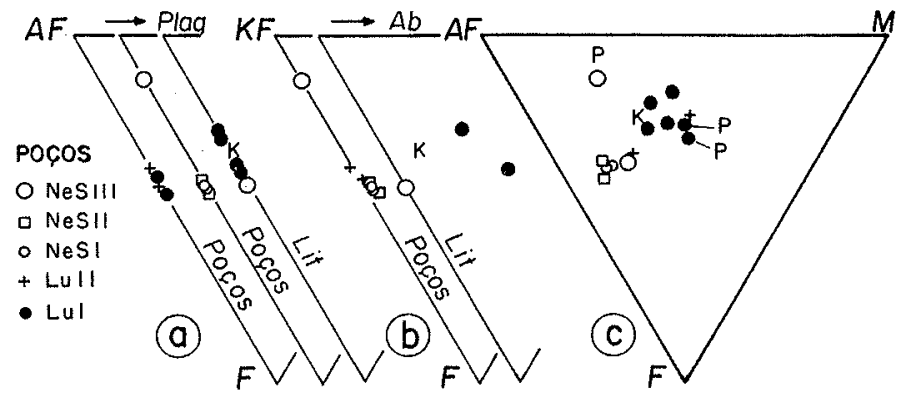

Figure II - Modal composition of lijavrites and associated rocks from Poģos de Caldas and other localities (data from: Table J; Johannsen 1938, Troeger 1935, Ferguson 1970). Heavy dots: lujavrites; circles: khibinites (NeS III) (specimens from Poģos de Caldas rocks and other places, cf. cited literature). $A b$ : albite; $A F$ : alkali feldspar; $F$ : feldspathoids; K: kakortokite; $K F$ : potash feldspar; M: mafic minerals. In c, Lu I and NeS III from Poços de Caldas are identified by the letter $P$. Lit: data from literature. 


\section{References}

Amaral G., Bushee J., Cordani U.G., Kawashita K., Reynolds J.H. 1967. Potassium-atgon ages of alkaline rocks from southern Brazil. Geochimica et Cosmochimica Acta, $31: 117-142$.

Bailey J.C. \& Gwozdz R. 1994. Li distribution in aegirine lujavrite, llímaussaq alkaline intrusion, South Greenland: role of cumulus and post-cumulus processes. Lithos, 31:207-225.

Barker D.S. 1987. Tertiary alkaline magmatism in Trans-Pecos, Texas. In: Fitton JG \& Upton BGJ. (eds.): Alkaline Igneous Rocks. Geological Society of London Special Publication, 30:415-431.

Barker D.S, Long L.E., Hoops G.K., Hodges F.W. 1977. Petrology and Rb-Sr isotope geochemistry of intrusions in the Diablo Plateau, northern Trans-Pecos magmatic province, Texas and New Mexico. Geological Societty of America Bulletin, 88:1437. 1446

Bjöınberg A.J.S. 1959. Rochas clásticas do planalto de Poços de Caldas. Boletim Faculdade Filosofia, Ciências e Letras, Universidade de São Paulo, n² 237, Geologia n' 18:64123.

Blaxland A.L., Van Breemen O., Steenfelt A. 1976. Age and origin of agpaitic magmatism at llímaussaq, south Greenland: Rb-Sr study. Lithos, 9:31-38.

Blaxland A.B., Van Breemen O., Emeleus C.H., Anderson J.G. 1978. Age and origin of the major syenite centers in the Gardar province of south Greenland: Rb-Sr studies. Geological Society of America Bulletin, 89, 231-244

Bushee J. 1974. A geochronological study of the alkaline massif of Pogos de Caldas. Geology and petrography of the lujavrite and nearby rocks, Pogos de Caldas. Brazil. Berkeley, $145 \mathrm{p}$. (Doctor of Philosophy Thesis, Department of Geology and Geophysics, UC Berkeley).

Chapman N.A., McKinley I.G., Shea M.E., Smellie J.Á.T. (eds.) 1992. The Poços de Caldas Project: Natural analogues in a radioactive repository. Part I. Joumal of Geochemical Exploration, 54:1-603.

Derby O.A. 1887. On nepheline rocks in Brazil, with special reference to the association of phonolite and foyaite. Quarterly Joumal of the Geological Society, 43:457-473.

Ellert R. 1959. Contribuicão à geologia do maciço alcalino de Poços de Caldas. Boletim da Faculdade Filosofia, Ciências e Letras, Universidade de São Paulo, n² 237, Geologia $\mathrm{n}^{\circ}$ 18:5-63.

Ferguson J. 1970. The differentiation of agpaitic magmas: the lllimaussaq intrusion, South Greenland. Canadian Mineralogist, 10:335-349.

Ferguson J. \& Pulvertaft T.C.R. 1963. Contrasted styles of igneous layering in the Gardar Province of south Greenland. Mineralogical Society of America Special Paper, 1:1021 .

Gualda G.A.R. 1998. Variaçöes químicas em minerais máficos e a evoluçăo de magmas apáricos do corpo lujaurítico-chibinítico do Anel Norte - maciso alcalino de Pocos de Caldas $(M G-S P)$. Unpublished Monograph, Instituto de Geociências, Universidade de São Paulo, $61 \mathrm{p}$.

Gualda G.A.R. \& Vlach S.R.F. 1996. Eudialitas-eucolitas do maciço alcalino de Poços de Caldas, MG-SP: quimismo e correlaçóes com o compottamento óptico. In Congresso Brasileiro de Geologia, 39, Salvador, 1996, Anais..., vol. 3, Salvador, SBG, p.3437 .

Gerasimovsky V.I., Volkov V.P., Kogatko L.N., Polyakov A.I. 1974. Kola Peninsula. In: Sorensen H. (ed.): The Alkuline Rocks; Wiley, New York, 206-220

Hamilton DL. 1961. Nephelines as crystallization temperature indicators. Jounal of Geology, 69:321-329

Hamilton D.L. \& MacKenzie W.S. 1960. Nepheline solid solution in the system NaAISiO $\mathrm{KAISiO}-\mathrm{SiO}_{2}$. Jownal of Perrology, 1:56-72.

Johannsen A. 1938 . A Descriptive Petrography of the Igneous Rocks. Volume IV. Part I: The feldspathoidal rocks. Part II: The peridotites and perknites. The University of Chicago Press, Clicago, 523 p.

Kawashita K Mahiques M.M. Ulbrich H.H. 1984. Idades Rb/Sr de nefelina sienitos do Anel Norte do macico alcalino de Pocos de Caldas, MG-SP. In Congresso Brasileiro Anel Norte do maciço alcalino de Poços de Caldas, MG-SP. In Congresso Brasileiro

Kogarko L.N. 1974. Role of volatiles. In: Sorensen H. (ed.): The Alkaline Rocks, Wiley, New York, 474-487

Larsen L.M. \& Sorensen H. 1987. The Ilímaussaq intrusion - progressive crystallization and formation of layering in an agpaitic magma. In: Fitton J.G. \& Upton B.G.J. (eds.): Alkaline Igneons Rocks. Geological Sociery of London Special Publication, 30, $473-488$

Machado J. 1888. Beitrag zur Petrographie der suedwestlichen Grenze Minas Gerais und Sāo Paulo. Tschermak's Mineralogische und Petrographische Mitteilungen, 9: 329360.

MacKenzie W.S. 1954. The orthoclase-microcline inversion. Mineralogical Magazine, 30:354-366.

Mathias M. 1974. Alkaline rocks of southern Africa. In: Sorensen H. (ed.)The Alkaline Rocks. Wiley, New York, 189-202.

Oliveira M.A.F., Morales N., Fúlfaro V.J. 1984. Projeto Bra Vista. UNESP, Rio Claro, SP, Brazil. Unpublished final report, SICCT, 1: $109 \mathrm{p}$.
Paslick C.R., Halliday A.N., Davies G.R., Mezger K., Upton B.G.J. 1993. Timing of Proterozoic magmatism in the Gardar province, south Greenland. Geological Socien of America Bulletin, 105:272-278.

Potter L.S. 1996. Chemical variation along strike in feldspathoidal rocks of the Eastern Alkalic Belt, Trans-Pecos magmatic province, Texas and New Mexico. Cantadian Mineralogist, 34:241-264.

Powell M. \& Powell R. 1977. A nepheline-alkali feldspar geothermometer. Contributions to Mineralogy' and Petrology, 62:193-204

Putzer H. 1976. Metallogenetische Provinzen in Suedanerika. Schweizerbart'sche, Stuttgart, $316 \mathrm{p}$.

Schorscher H.D. \& Shea M.E. 1992. The regional geology of the Poços de Caldas alkaline complex: mineralogy and geochemistry of selected nepheline syenites and phonolites. Part I Journal of Geochemical Exploration, 54:1-24.

Shand S.J. 1929. The geology of Pilansberg (Pilaan's Berg) in the western Transvaal, a study of alkaline rocks and ring-intrusions. Geological Society of South Africa Transactions, 3:97-156.

Shand S.J. 1947. Eriptive Rocks. 3d. edition, Murby, London, 488 p.

Shea M.E. 1992. Isotopic geochemical characteristics of selected nepheline syenites and phonolites from the Poços de Caldas alkaline complex, Minas Gerais, Brazil. Part I. Joumal of Geochemical Exploration, 54:173-214

Smith K.L. \& McLaren A.C. 1983. TEM investigation of a microcline from a nepheline syenite. Physics and Chemistry of Minerals, 10:69-76.

Sonoki I.K. \& Garda G.M. 1988. Idades K/Ar de rochas alcalinas do Brasil meridional o Paraguai oriental: compilacão e adaptação às novas constantes de decaimento. $B 0$ letim IG-USP Série Cientifica, 19:63-85.

Sood M K 1981. Modern Igneous Petwlogy. Wiley, New York, $244 \mathrm{p}$

Sorensen $H$. 1970. Internal structures and geological setting of the three agpaitic intrusions - Khibina and Lovozero of the Kola peninsula and Ilímaussaq, south Greenland. Canadian Mineralogist, 10:299-334.

Sorensen $\mathrm{H}$. 1974a. Alkali syenites, feldspathoidal syenites and related lavas. In:Sorensen H. (ed.):The Alkaline Rocks, Wiley, New York, 22-52.

Sorensen H. 1974b. Glossary of alkaline and related rocks. In: Sorensen, H. (ed.):The Alkaline Rocks. Wiley, New York, 588-577

Sorensen H \& Larsen L.M. 1978. Aspects of crystallization of volatile-rich peralkatine undersaturated magmas - exemplified by the Illimaussaq intrusion, south Greenland. Volume Djalma Guimarães, Jomal de Mineralogia, Recife, 7:135-142.

Troeger W.E. 1935. Spezielle Petrographie der Ertutivgesteine. Deutsche Mineralogische Gesellschaft, Berlin, 360 p.

Ulbrich $\mathrm{H} H$. 1984 A petrografu a estrutura eo quinismo de nefelina sienitos do macico alcalino de Pocos de Caldas, MG-SP. São Paulo, 585 p. (Habilitation Thesis, Instituto de Geociências da Universidade de São Paulo)

Ulbrich H.H. \& Ulbrich M.N.C. 1992 . O maciço alcalino de Poços de Caldas, MG-SP: características petrográficas e estruturais. In Congresso Brasileiro de Geologia, 37. características petrográficas e estruturais. In Congresso Brasileiro de

Ubrich M.N.C. 1983 . Aspectos mineralóg icos e petrológicos de nefelina sienitos do macigo alcalino de Pogcos de Caldas; MG-SP. São Paulo, 369 p. (Doctor's thesis, Inscifu a de Geociências, Universidade de São Paulo).

Ulbrich M.N.C. 1985. Geothermometry of the Pocos de Caldas nepheline syenites, southern Brazil. Anais Academia Brasileira de Ciências, 57: p.131.

Ulbrich M.N.C. 1993. Mineralogy of nepheline syenites from the Poços de Caldas alkaline massif, SE Brazil: chemistry, X-ray data and microtextures of feldspars. Revista Brasileira de Geociências, 23:388-399.

Ulbrich M.N.C, Gomes C.B., Ulbrich H.H. 1984. Nefelina sienitos do maciço alcalino de Poços de Caldas, MG-SP: características mineralógicas e petrológicas. In: Congresso Brasileiro de Geologia, 33, Rio de Janeiro, 1984. Anais ... Rio de Janeiro, SBG, p.4352-4376.

Upton B.G.J. 1974. The alkaline province of south-west Greenland. In: Sorensen H. (ed.): The Alkaline Rocks. Wiley, New York, 221-238.

Utsumi O Oliveira A.G. Parisi C.A. Williams D.D. 1971. Roteiro de excursōes: Pocos de Caldas. In: Congresso Brasileiro de Geologia, 25, São Paulo, 1971. Roteiro Excursões, Boletim Especial ... São Paulo. SBG, v. 2, p.7-13.

Vlasov K A. Kuz'menko M.Z., Es'kova E.M. 1966. The Lovozero Alkali Massif: Hafner: New York, 627 p.

Zaitsev A.N. 1996. Rhombohedral carbonates from carbonatites of the Khibina massif, Kola Peninsula, Russia. Canadian Mineralogist, 34:453-468.

Manuscrito A-1086

Recebido em 10 de abril de 1999 Revisão dos autores em 30 de março de 2000 Revisão aceita em 14 de abril de 2000 